PD-121

音楽聴取前にフォーカシング経験の ない学生の音声で提供されたフォー カシング教示が心理的反応に及ぼす 影響一聴取者の特性不安の程度によ る検討一

栗野理恵子 ${ }^{1}$

(皇學館大学)

キーワード : フォーカシング教示, 音楽聴取, 心理的反応

これまで音楽聴取前のフォーカシング教示の提供が, 音楽聴取後の心 理的反応として内的な体験過程を促すことを明らかにしたが（栗野, 2017)，フォーカシング教示の提供者がフォーカシング経験者であること がこのような反応をもたらした可能性も考えられる。そこで本研究では, フォーカシング経験のない男子大学生が読みあげた教示を録音し，その 音声を音楽聴取前に提供する条件と，教示がない条件における音楽聴取 後の心理的反応を検討した。心理的反応は多面的感情状態尺度 - 短縮版 をVAS で測定し，音楽聴取後における変化率を算出して分析した。な お, 音楽聴取者側の特性として特性不安を測定し, その程度の違いによ る比較を行った。その結果, 活動的快, 非活動的快, 抑うつ不安の変化 率に特に違いは認められなかったが, 敵意の変化率において違いが認め られ, 教示がある場合は特性不安が低い人は減少し, 不安が高い人は增 大することが示された。フォーカシング体験のない男子学生の音声によ る教示によって心理的反応の異なりが生じたことから, 教示の内容が聴 取者の内省を促したと考えられた。また，特性不安が高い場合の反応特 徵についてさらなる検討の必要性が示された。

連絡先 E-mail：r-kurino@kogakkan-u.ac.jp

\section{PD-123＼cjkstart乳幼児の母親の抑うつ傾向に反すう は影響しているのか?}

○日下部典子 ${ }^{1}$

(福山大学)

キーワード：幼児の母親，抑うつ傾向，反すう

幼児の母親の 3,4 割に抑うつ傾向が認められ（日下部，2017），その 軽滅は母親だけでなく子どもの健全な心身の発達にとって重要である。こ れまでにサポートが一つの有効な方法であることが明らかとなっている が, サポート希求が難しい母親も多く, 有効な抑うつ傾向を軽隇する介 入がされているとは言い難い。抑うつ傾向に関連する要因は様々なこと があり，妊娠中の抑うつ傾向，子育てで生じるストレッサー（子どもが 言うことを聞かない，一人で子育てをしているなど)，性格，サポート状 況等があるが (日下部，2005），その一つとして「反すう」が考えられる。 これまでに大学生を対象とした研究で, ネガティブな内容の反すうは抑 うつと関連していることが明らかとなっている（たとえば伊藤・竹中 · 上里 (2001) 等)。しかし, 乳幼児の母親に扔ける抑うつ傾向と反すうの 関係が明らかにされたとは言い難い。加えて，ポジティブな内容を反す うすることが抑うつにどのような影響を及ぼすのかをあわせて検討する ことも必要である。反すうと抑うつ傾向の関係を明らかにすることで，母 親への有効な介入が期待される。

\section{PD-122大学生のアルコール使用の心理的背景 一内的作業モデルとパーソナリティ特 性に着目して一}

○相山かれん ${ }^{1}$, 中島 香澄 ${ }^{1}$, 稗田 里香2,

(1東海大学, ${ }^{2}$ 武蔵野大学)

キーワード：飲酒，内的作業モデル，依存症

大学生のアルコール使用の心理的背景について，SEMによる因果モデ ルの検討を行った。大学生 380 名を対象に, 質問紙調查; 「内的作業モデ ル尺度」(戸田, 1988), 「日本語版 UCLA 孤独感尺度（第 3 版）」(舛田 · 田高·臺, 2012), 「信頼感尺度」(天貝, 1995), 「自尊感情尺度」(桜井, 2000),「成人用過剩適応傾向尺度」(水澤，2014）「「アルコール使用障害 特定テスト」(WHO, 2001 小松・吉本訳2011）（AUDIT）を実施した。 結果, 自尊感情が高く孤独感が低いほど安定型の内的作業モデル (IWM) の得点が高くなり AUDIT 得点が高まることが示され，飲酒はむしろ人 との良好な関係性との関連が推測される。さらに飲酒者のみを対象に分 析したところ，回避型のIWM の得点が高く孤独感が強いほど不信が強ま り AUDIT 得点が高くなるモデルが示された。自己治療仮説（Khantzian \& Albanese, 2008）に基づくと, 関係性の中での孤独感や不信を瘾そう と飲酒することが，依存症に罹患するリスクを高めると考えられる。両 モデルから，飲酒習慣は必ずしも不健康な心理状態から生じるわけでは ないが，依存症のリスクについては対人関係の問題を背景に持つことが 明らかとなった。

連絡先 E-mail：karen.aiyama@gmail.com

\section{PD-124＼cjkstart社交不安におけるコルチゾール反応の 程度が不安反応の再発に及ぼす影響}

\author{
森石 千尋1, 前田 駿太 ${ }^{2}$, 荻島 大凱 ${ }^{1 . \#}$, 嶋田 洋德 \\ ( ${ }^{1}$ 早稲田大学, ${ }^{2}$ 東北大学) \\ キーワード：コルチゾール，再発，社交不安
}

目的

社交不安における再発の問題に対し，急性のコルチゾール反応が再発 の中核である消去記憶の想起の阻害を通して，再発に影響を及ほすすかど うか検討することを目的とした。

方法

一定の社交不安症状を有する大学生および大学院生 39 名（女性25名, 男 性14名, 平均年齢 $21.6 \pm 2.1$ 歳）のデー夕を対象とした。1 日目はCS+ に対する消去記憶の学習を目的とした恐怖条件づけ課題に従事した。翌 日, 急性の心理社会的ストレス負荷課題に従事し, その後再発を検討し た（再発テスト）。ストレス課題に対するコルチゾール反応の程度 (Responder, Non-responder) によって再発の程度を比較した。なお， 「早稲田大学人を対象とする研究に関する倫理審查委員会」による承認を 受けた（承認番号：2019-011）

結果

再発テスト時において, Responder と Non-responder でCS+に対する 不安反応 (主観指標, 瞳孔径, 皮膚電気反応) の程度に差は示されなかっ た。なお，反応の程度にかかわらず，コルチゾールの分泌総量はCS+に 対する不安，ネガティブな感情価と正の相関を示した。

考察

不安反応の再発には，コルチゾール反応の程度だけではなく，分泌量 が影響を及ぼす可能性が示唆されたと考えられる。

連絡先 E-mail：c-porto@toki.waseda.jp 